\title{
EXCURSION TO STANMORE HILL AND BUSHEY HEATH.
}

\author{
Saturday, May i7Th, Igrg.
}

REPORT BY G. Barrow, F.G.S., Director of the Excursion.

LEAVING Pinner Station and proceeding northwards toward the south-west end of the irregularly shaped outlier of the High-level Gravels, a halt was made a little way up the hill. The Director pointed out that they were crossing the London Clay, not far from its base, as the Reading Beds crop out close to Pinner Station. This had a bearing on the stratigraphical position of the gravels to be examined, as by the time they were reached a sufficient thickness of the London Clay could not have been passed over for the gravels to be part of the overlying Eocene Beds, as had formerly been suggested by Reid and others. This evidence was repeated at the top of the hill. where a well and boring had proved the thickness of the London Clay beneath the high-level gravel.

At some distance below the 400-foot contour, one side of the road was kept quite wet by springs issuing from the base of the gravel and the water did not disappear till the deposit was reached. About this contour the gravel comes on and its composition can be fairiy well seen in the banks about the roadsides, though no good sections occur. By far the greater part of the pebbles are derived from the Reading Beds, a few bits of broken flint can be found and a moderate number of the small white quartz-pebbles; more of these would be visible if the ground were wet. Flint-pebbles burnt by forest-fires are often a feature of the first 9 or I 2 inches of the soil over the whole of the plateau. Plenty of these reddened stones were found showing the small circular cavities left by bits breaking off, practically exploding from, the upper heated surface. They are quite unlike " pot-boilers " and attention was specially drawn to them at this natural wood or forest, because many hundred similar small burnt rounded pebbles were found in the new Albert Dock excavations. They had been washed down, together with the rotted wood lying above them, when the river terrace, on which both were formed, became submerged. It was at first thought that they suggested human agency. Proceeding along the road the extent of the old gravel-workings was noted, the deposit having been dug almost entirely away on both sides; the small irregular mounds scattered over the ground being the refuse left behind. Between the mounds at this time of year there are a number of small pools of water and wet places, due to the water from the gravel being held up by the underlying clay. In this part of the area this clay is 
not London Clay, but a rather pale-coloured and loamy brickearth that underlies and is connected with the gravel ; where thicker it was formerly used for brickmaking. Close to the Kilns, shown on the Old Series map, the director pointed out the site of some workings in this clay that were in operation only some two years ago, but are now grassed over. A brief description of them has been given by Mr. R. W. Pocock in the Summary of Progress for I9I3, p. 33. The digging of the clay ceased when the London Clay was reached.

Mrs. Martin, whose house was on the site of the older and larger brickworks at the Kilns, had kindly consented to the party passing through the garden and visiting the old pit and a new section made in the gravel, part of which has here been left. The old clay-pit is now filled with water and it is by the side of this pond that the recent excaration has been made exposing about 6 feet of the gravel. In structure it is unbedded and composed of materials of different sizes, arranged so that the interspaces between the larger stones are filled in with smaller ones of all sizes, eventually passing to fine sand. It has thuss the features of a beach deposit and its component materials are arranged exactly as in the High-level Gravel in the fit on Little Heath recently visited by the Association. Of the larger stones fully go per cent. by bulk have been derived from the Reading Beds (possibly some may have come from the basement bed of the London (lay), in most cases retaining their rounded form. The noded surtaces are preserved in much the greater number, but some have been smoothed and the noding more or less worn away. The bulk of the Reading-pebbles here, and where seen by the roadsides, are between one and a half and two inches long; a moderate number are larger and a few much larger. Pebbles less than two inches long are fairly abundant, but less easily seen; many of these have smooth and rather Hattened surfaces, a feature that is also shown by broken fragments of these pebbles.

The number of fairly large flints derived directly from the Chalk is small, and those present shov little well-marked rounding; the points of the horns have been broken off, but the stumps remain. In one of the bigger specimens the original rind is largely preserved, and generally speaking the condition of the few larger flints present suggests that they have not travelled far from their original source and thus could have come only from the north.

A fair amount of the material filling the interspaces between the larger stones was collected and has been washed. The largest pebbles, forming about one fourth of the whole by bulk, are between one half and three quarters of an inch long and consist of Reading-pebbles and bits of flint. The pebbles are generally smoothed and often polished on one or both sides; 
they are always flatter than in their original form in the Reading Beds. Fragments of flint are the more common, but less rounded; some of them are obviously rather worn portions of the horns of the original flint. The stones next in size vary more in composition; though a few may be Reading, the bulk are fragments of flint, much more worn, though still flat rather than round. Pebbles of white quartz of this size are fairly common, but they are smaller than is usual in these deposits; since they were set free from the Lover Greensand, the burnished surfaces and the dreikanter-like form of many of the orisinal pebbles have been lost. These pebbles, between a quarter and half an inch long, form rather less than a fourth of the infilling material. Of the still smaller but still easily identifiable pebbles forming about one eighth by bulk of the whole, white quartz is probably the dominant constituent; the quantity thus set free by washing is much greater than an examination of the dry material in the field would lead one to expect. The remainder consists of flat and worn fragments of flint, some of which may be fragments of Reading-pebbles.

The material that is still too coarse to be called sand is essentially a mixture in almost equal parts, of white quartz and yellowish grains (quartz?), which latter could not have been derived from the Greensand. There is not a large quantity of this and the few darker grains in it have not been determined.

The sand forms nearly an eighth of the whole and it also consists of a mixture of white and yellow grains.

The final residue is a yellowish-brow'n clay; there is more of it than might have been expected; from its habit of sticking to the surfaces of the slightly larger smoothed pebbles there is little doubt that it was washed in from above: the smaller stones are fairly free from it. The whole of the washed material has been preserved and will be deposited, together with similar material from other occurrences of the High-level Gravel for comparison, in a small reference collection.

From the above notes it is seen that this deposit, and that at Little Heath. are composed of the same materials, but in different proportions, while the pebbles differ also in size. At Little Heath large flints form one half of the deposit by bulk, while at Bushey Heath they do not form more than one twentieth part; moreover the very large flints are entirely absent in the more southerly gravel. The Reading pebbles, though forming a far larget portion of the whole deposit, are on the average much smaller than at Little Heath. The white quartz-pebbles show a similar diminution in size; they are also more broken and eroded, though the proportion, by number, is equally great. An important point is the apparent absence of fragments of Inoceramus, so common at Little Heath; obriously these shell fragments would not travel far. Thus everything points to 
the identity in age and origin of the two gravels; the differences are such as would naturally occur in the components travelling from north to south.

The discovery of this section, showing the original structure of the Gravel was quite unexpected; the Director had never seen it before and he doubted if half a dozen geologists now living had done so. As a rule the faces exposed in these old pits in the High-level Gravels show nothing but an agglomeration of stones of different sizes. The result of this excursion is to suggest the desirability of making new and clear faces in other localities, such as Potters Bar, etc. The occurrences of the High-level (Pebble) Gravel are fairly well shown on the Old Series map, sheet 7 , and at Potters Bar it is overlain by Chalky Boulder Clay, at a height of about 420 feet above sealevel. Proceeding from this locality toward the place where they were now standing it will be seen that these gravels maintain much the same height practically to Shenley, where they had recently been examined by the Association. These deposits then begin to rise till at the cross roads on Bushey Heath, their surface is 5io feet above sea-level. But the Chalky Boulder Clay descends as it passes down the Colne Valley and at the point immediately below Bushey Heath it is only at 2 ro feet above Ordnance Datum, and rests on the Glacial Gravel. Thus the Chalky Clay instead of being above the High-level Gravel, is now 300 feet below it, so that there is clearly no connection between them. The Colne valley did not exist when these high-lying gravels were formed, while it had been eroded practically to its present level when the glacial deposits were left in it.

Further over the area, stretching from Northolt and Potters Bar to a point well west of Barnet, these higher gravels contain a considerable amount of chert from the Lower Greensand (as pointed out by Mr. R. W. Pocock), so that it and its associated small quartz-pebbles must have come from the south, through one of the gaps in the Chalk escarpment. Further to the west it disappears, as little or none has been found at Bushey Heath, where the material came mainly from the north ; it is almost certain that there is no chert in the Lower Greensand north of the Chilterns.

The party then proceeded to another pit some distance to the north-east of the Kilns, and on the west side of the Watford Road; though in use only a few years ago, it has been largely filled with rubbish, and the small face still visible showed only the usual agglomeration of stones of various sizes.

The party took tea at the Alpine Corner House, 5io feet above sea-level, and the highest point in Middlesex. They afterwards crossed Stanmore Common and proceeded along the lane leading to Brockley Hill. From this lane an excellent 
view southwards was obtained, and the position of Hampstead Heath located, where there is another occurrence of the Highlevel Gravel, with its abundant small quartz-pebbles; this too, has been visited more than once by the Association.

The greater portion of the party descended Brockley Hill, returning to London by the tram; but three went on to Elstree to see if the gravel was present at this village. Turning up a side lane from the main street the deposit was easily found in place, but its distribution is curious, as it seems absent from the crest of the hill. Fither it was deposited against a bank of London Clay or its base slopes up southward at a greater rate than on Bushey Heath. The gravel is not shown on the old map at this locality, or at Woodcock Hill; it thus has to be carefully traced and mapped between Brockley Hill and Barnet Gate. The gravel may have been dug away and even the brick-clay partly removed, but there will be no difficulty in tracing remnants, if they ever existed. The party of three returned home by the Midland Railway from Elstree.

\section{REFERENCES.}

Geological Survey Map, Old Series, Sheet 7. London District, Sheet I. Ordnance Map, Iin., New Series, 256.

I889.-Mem. Geol. Survey, Geology of London, vol. r, pp. 250-296. I905.-Proc. Geol Assoc., vol. xix., p. 1. 